\title{
ANALIZA INFEKCJI WYSTĘPUJĄCYCH U NOWORODKÓW HOSPITALIZOWANYCH W KLINICE NEONATOLOGII
}

\section{ANALYSIS OF INFECTION IN NEWBORNS HOSPITALIZED IN A NEONATOLOGY CLINIC}

\author{
Katarzyna Szymoniak ${ }^{1, a}$, Agata Słomińska ${ }^{2, b}$, Dorota Ćwiek ${ }^{1, c}$ \\ 1 Zakład Położnictwa i Patologii Ciąży, Wydział Nauk o Zdrowiu, Pomorski Uniwersytet Medyczny, Szczecin \\ ${ }^{2}$ Klinika Neonatologii, Samodzielny Publiczny Szpital Kliniczny nr 1, Pomorski Uniwersytet Medyczny, Szczecin \\ ${ }^{\text {a }}$ https://orcid.org/0000-0003-3941-7340 \\ ${ }^{\mathrm{b}} \mathrm{https}: / /$ orcid.org/0000-0003-3329-0852 \\ ${ }^{c}$ https://orcid.org/0000-0002-4908-9056
}

DOI: https://doi.org/10.20883/pielpol.2021.17

\section{STRESZCZENIE}

Wstęp. Narodziny dla noworodka wiążą się ze zmianą otoczenia, ze względnie sterylnego środowiska wewnątrzmacicznego na pozamaciczny. Choroby infekcyjne pozostają jednym z głównych wyzwań w medycynie wśród noworodków.

Cel. Celem pracy było określenie czynników determinujących rodzaj infekcji występujących u noworodków hospitalizowanych w Klinice Neonatologii PUM w Policach.

Materiał i metody. Do badań zakwalifikowano 55 dzieci przebywających w Klinice Neonatologii PUM w SPSK nr 1 w Policach. Powyższa praca jest jednoośrodkowym badaniem obserwacyjnym bazującym na retrospektywnej analizie danych. Analizę statystyczną wykonano w programie The R Project w wersji 3.6.2.

Wyniki. Najczęstszym rodzajem infekcji wśród dzieci było zapalenie płuc $(56,36 \%)$. U wcześniaków istotnie częściej występowało zapalenie płuc $(77,42 \%)$. Dzieci urodzone zarówno poprzez poród fizjologiczny, jak i cięcie cesarskie częściej chorowały na zapalenie płuc (odpowiednio 40,0\% i 65,71\%). U noworodków urodzonych w stanie średnim i w stanie dobrym według skali Apgar rozpoznano zapalenie płuc (78,95\%; 44,44\%). Ponad 52,0\% dzieci urodziło się z wagą urodzeniową $\leqslant 2500 \mathrm{~g}$ i istotnie częściej chorowały one na zapalenie płuc $(72,41 \%)$. W przypadku pobranych wymazów u dzieci przeważał wynik ujemny $(58,18 \%)$, tak samo jak w wypadku pobranych posiewów (70,91\%). Najczęściej wśród dzieci występowały bakterie chorobotwórcze, typu Escherichia coli (14,55\%), Klebsiella pneumoniae $(14,55 \%)$ oraz Enterobacter cloacae (9,09\%).

Wnioski. 1) Wcześniactwo oraz niska masa urodzeniowa są istotnymi czynnikami determinującymi występowanie zapalenia płuc u noworodków. 2) Przedwczesne odpływanie płynu owodniowego nie ma szczególnego związku z występowaniem infekcji u noworodków, ale, jeśli wody płodowe odpływają powyżej 6 godzin, dominuje zapalenie płuc. 3) Dodatni wynik nosicielstwa GBS u matki nie jest jednoznacznym ryzykiem transmisji wertykalnej na noworodka w okresie okołoporodowym.

SŁOWA KLUCZOWE: infekcja, noworodek, zapalenie płuc.

\begin{abstract}
Introduction. The most important change a person encounters in life is during their birth. There is a change in the environment from a relatively sterile in-utero environment to a retrouterine through. Infectious diseases remain one of the main challenges in medicine among newborns.

Aim. The aim of the study was to determine the type of infection occurring in newborns hospitalized at the PUM Neonatology Clinic in Police.

Material and methods. Fifty-five children from the PUM Neonatology Clinic at SPSK No. 1 in Police were qualified for the study. This paper is a single-centre observational study based on retrospective data analysis. Statistical analysis was performed in The R Project program, version 3.6.2.

Results. The most common type of infection among children was pneumonia (56.36\%). Premature babies had a significantly higher incidence of pneumonia (77.42\%). Children born both through physiological delivery and caesarean section were more likely to have pneumonia $(40.00 \%$ and $65.71 \%)$. Pneumonia $(78.95 \%$; $44.44 \%$ ) was diagnosed in medium and good fairing newborns according to the Apgar scale. Over $52 \%$ of children were born with birth weights $\leqslant 2500 \mathrm{~g}$, and significantly more often, they suffered from pneumonia (72.41\%). In the case of swabs collected from the children, the negative result prevailed $(58.18 \%)$, as in the case of collected cultures $(70.91 \%)$. The most common types of pathogenic bacteria among children were: Escherichia coli (14.55\%), Klebsiella pneumoniae (14.55\%) and Enterobacter cloacae (9.09\%).

Conclusions. 1) Prematurity and low birth weight are significant risk factors that affect the occurrence of pneumonia in newborns. 2) Premature drainage of amniotic fluid has no particular effect on the occurrence of infections in newborns, but if fetal water drains for more than 6 hours, pneumonia predominates. 3) Positive maternal GBS carriage is not a clear risk of vertical transmission to the newborn in the perinatal period.
\end{abstract}

KEYWORDS: infection, newborn, pneumonia. 


\section{Wstęp}

Narodziny dla noworodka związane są ze zmianą otoczenia, ze względnie sterylnego środowiska wewnątrzmacicznego na pozamaciczny. Okazuje się, że bakterie chorobotwórcze są najczęściej występującymi patogenami wśród dzieci, a tydzień ciąży i masa urodzeniowa należą do najważniejszych czynników wpływających na infekcje. Ma to związek z niedojrzałością układu odpornościowego noworodka oraz gorszymi parametrami wentylacyjnymi płuc. Między innymi z tych powodów szybkie rozpoznanie zakażenia jest konieczne. Choroby infekcyjne wśród noworodków pozostają jednym z głównych wyzwań w medycynie, szczególnie w przypadku rosnącej liczby przedwcześnie urodzonych dzieci, które narażone są na duże ryzyko inwazyjnych patogenów przez dłuższy czas. Dlatego niezwłocznie potrzebne są nowe rozwiązania do wczesnej identyfikacji zagrożonych noworodków, które umożliwiłyby interwencję zapobiegawczą i profilaktyczną.

\section{Cel pracy}

Celem pracy było określenie czynników determinujących rodzaj infekcji występujących u noworodków hospitalizowanych w Klinice Neonatologii PUM w Policach.

\section{Materiał i metody}

Do badania zakwalifikowano 55 noworodków przebywających w Klinice Neonatologii PUM w SPSK nr 1 w Policach. Badanie miało charakter retrospektywny. Kryterium włączenia noworodka do badań było występowanie infekcji u noworodka. Do analizy wykorzystano dane z trzech okresów: ciąży (infekcje i choroby występujące u matki w czasie ciąży, GBS, PROM i czas odpływania wód płodowych), okresu porodu (czas porodu, sposób ukończenia ciąży, waga urodzeniowa noworodka i skala Apgar) oraz okresu połogu (wyniki badań noworodka: CRP, WBC, wymazy i posiewy). Noworodki kwalifikowano do badania na podstawie historii choroby i karty informacyjnej, która zawierała rozpoznanie choroby infekcyjnej (ICD-10), jej przebieg oraz leczenie. Badania przeprowadzono pomiędzy grudniem 2018 r. a listopadem 2019 r. Z uwagi na retrospektywny charakter pracy nie była konieczna zgoda Komisji Bioetycznej. Na przeprowadzenie badań uzyskano zgodę kierownika Kliniki. Analizę statystyczną wykonano w programie The R Project w wersji 3.6.2. R Core Team (2019). Do badania zależności pomiędzy analizowanymi zmiennymi zastosowano test dokładny Fishera (dla tabel $2 \times 2$ ) oraz test Fishera-Freemana-Haltona (dla tabel większych niż $2 X$ 2). W analizie przyjęto poziom istotności $p=0,05$.

\section{Wyniki}

Na podstawie analizy materiału wykazano, iż 56,36\% noworodków urodziło się przedwcześnie, przy czym prawie $64,0 \%$ drogą cięcia cesarskiego. Mediana czasu odpływania płynu owodniowego wynosiła niespełna 7 dni. W badaniu utworzono 3 grupy, do których przypisywano każdego noworodka według jego stanu: 1. Stan ciężki (0-3 pkt), 2. Stan średni (4-7 pkt), 3. Stan dobry (8-10 pkt). W stanie ciężkim nie urodził się żaden noworodek, natomiast w stanie średnim 34,55\% dzieci, a w stanie dobrym 65,45\% badanych. Ponad 52,0\% dzieci urodziło się z wagą urodzeniową $\leqslant 2500 \mathrm{~g}$. Przedwczesne odpływanie płynu owodniowego miato miejsce w prawie 42,0\% przypadków, a u niespełna $4,0 \%$ rodzących płyn przybierał kolor zielony. GBS był dodatni u 14,55\% z 21 badanych kobiet. U 61,82\% ciężarnych nie pobrano wymazu ze względu na niską ciążę. Infekcje podczas ciąży występowały jedynie u 20,0\% ankietowanych, a choroby współistniejące miały miejsce u prawie $64,0 \%$ badanych. Antybiotykoterapia była stosowana u wszystkich dzieci w 100,0\%. Analizując badania diagnostyczne z krwi u noworodków, wykazano, że białko C-reaktywne u ponad 43,0\% dzieci dało wynik dodatni, natomiast podwyższoną liczbę leukocytów we krwi stwierdzono u 38,18\% noworodków. W przypadku pobranych wymazów u dzieci przeważa wynik ujemny, czyli 58,18\%, tak samo jak w wypadku pobranych posiewów, gdyż wynik ujemny występuje u 70,91\% noworodków. Najczęstszym rozpoznaniem końcowym infekcji u dzieci było zapalenie płuc, stanowiło ono ponad 56,0\% przypadków (Tabela 1).

Tabela 1. Charakterystyka badanej grupy Table1. Characteristics of the study group

\begin{tabular}{|c|c|c|}
\hline \multicolumn{2}{|c|}{ Parametr/Parameter } & Ogół N (\%)/Total N (\%) \\
\hline \multirow{3}{*}{$\begin{array}{l}\text { Czas odpływania wód/ } \\
\text { Time of water breaking }\end{array}$} & śr $\pm S D / M e a n \pm S D$ & $61,12 \pm 86,99$ \\
\hline & mediana/median & 6,91 \\
\hline & kwartyle/quartiles & $3,77-103,24$ \\
\hline \multirow{3}{*}{$\begin{array}{l}\text { Czas porodu/ } \\
\text { Time of delivery }\end{array}$} & Wcześniak/Premature & $31(56,36 \%)$ \\
\hline & Donoszony/Full-term & $24(43,64 \%)$ \\
\hline & Przenoszony/Postmature & $0(0,00 \%)$ \\
\hline \multirow{2}{*}{$\begin{array}{l}\text { Rodzaj porodu/ } \\
\text { Type of delivery }\end{array}$} & Drogami natury/Natural & $20(36,36 \%)$ \\
\hline & $\begin{array}{c}\text { Cięcie cesarskie/Caesa- } \\
\text { rean section }\end{array}$ & $35(63,64 \%)$ \\
\hline \multirow{3}{*}{$\begin{array}{l}\text { Skala Apgar/ } \\
\text { Apgar score }\end{array}$} & $\begin{array}{l}\text { Stan ciężki/Severe } \\
\text { condition }(0-3)\end{array}$ & $0(0,00 \%)$ \\
\hline & $\begin{array}{l}\text { Stan średni/Medium } \\
\text { condition (4-7) }\end{array}$ & $19(34,55 \%)$ \\
\hline & $\begin{array}{c}\text { Stan dobry/Good condi- } \\
\text { tion }(8-10)\end{array}$ & $36(65,45 \%)$ \\
\hline \multirow{2}{*}{$\begin{array}{l}\text { Waga urodzeniowa/ } \\
\text { Birth weight }\end{array}$} & $>2500 \mathrm{~g}$ & $26(47,27 \%)$ \\
\hline & $\leqslant 2500 \mathrm{~g}$ & $29(52,73 \%)$ \\
\hline \multirow{2}{*}{$\begin{array}{l}\text { PROM/ } \\
\text { Premature rupture } \\
\text { of membranes }\end{array}$} & Tak/Yes & $23(41,82 \%)$ \\
\hline & $\mathrm{Nie} / \mathrm{No}$ & $32(58,18 \%)$ \\
\hline
\end{tabular}




\begin{tabular}{|c|c|c|}
\hline \multirow{3}{*}{$\begin{array}{l}\text { Zabarwienie wód } \\
\text { płodowych/Colour } \\
\text { of amniotic fluid }\end{array}$} & Czyste/Clear & $21(38,18 \%)$ \\
\hline & Zielone/Green & $2(3,64 \%)$ \\
\hline & Brak danych/No data & $32(58,18 \%)$ \\
\hline \multirow{3}{*}{$\begin{array}{l}\text { GBS u matki/Group B } \\
\text { streptococcus } \\
\text { in mother }\end{array}$} & Tak/Yes & $8(14,55 \%)$ \\
\hline & $\mathrm{Nie} / \mathrm{No}$ & $13(23,64 \%)$ \\
\hline & Brak wyniku/No result & $34(61,82 \%)$ \\
\hline \multirow{2}{*}{$\begin{array}{l}\text { Infekcje u matki/ } \\
\text { Infections in mother }\end{array}$} & Tak/Yes & $11(20,00 \%)$ \\
\hline & $\mathrm{Nie} / \mathrm{No}$ & $44(80,00 \%)$ \\
\hline \multirow{2}{*}{$\begin{array}{l}\text { Antybiotykoterapia } \\
\text { u noworodka/Antibiotic } \\
\text { therapy in newborn }\end{array}$} & Tak/Yes & $55(100,00 \%)$ \\
\hline & $\mathrm{Nie} / \mathrm{No}$ & $0(0,00 \%)$ \\
\hline \multirow{2}{*}{$\begin{array}{l}\text { Choroby wspótistnieja- } \\
\text { ce u matki/Comorbidi- } \\
\text { ties in mother }\end{array}$} & Tak/Yes & $35(63,64 \%)$ \\
\hline & Nie/No & $20(36,36 \%)$ \\
\hline \multirow[b]{2}{*}{ CRP/C-reactive protein } & W normie/Normal & $31(56,36 \%)$ \\
\hline & $\begin{array}{l}\text { Powyżej normy/ } \\
\text { Above norm }\end{array}$ & $24(43,64 \%)$ \\
\hline \multirow{2}{*}{$\begin{array}{l}\text { Leukocytoza/ } \\
\text { Leukocytosis }\end{array}$} & W normie/Normal & $34(61,82 \%)$ \\
\hline & $\begin{array}{l}\text { Powyżej normy/ } \\
\text { Above norm }\end{array}$ & $21(38,18 \%)$ \\
\hline \multirow{2}{*}{ Wymaz/Smear } & Dodatni/Positive & $23(41,82 \%)$ \\
\hline & Ujemny?Negative & $32(58,18 \%)$ \\
\hline \multirow{2}{*}{ Posiew/Culture } & Dodatni/Positive & $16(29,09 \%)$ \\
\hline & Ujemny/Negative & $39(70,91 \%)$ \\
\hline \multirow{4}{*}{$\begin{array}{l}\text { Rozpoznanie końcowe/ } \\
\text { Final diagnosis }\end{array}$} & $\begin{array}{l}\text { Zapalenie płuc/ } \\
\text { Pneumonia }\end{array}$ & $31(56,36 \%)$ \\
\hline & $\begin{array}{c}\text { Zakażenie okołoporodo- } \\
\text { we/wewnątrzmaciczne/ } \\
\text { Perinatal/intrauterine } \\
\text { infection }\end{array}$ & $9(16,36 \%)$ \\
\hline & $\begin{array}{l}\text { Inne: posocznica, zaka- } \\
\text { żenie grzybicze, zapale- } \\
\text { nie spojówek, zapalenie }\end{array}$ & \\
\hline & $\begin{array}{l}\text { opon m-r, zakażenie } \\
\text { CUN, ZUM., zapalenie } \\
\text { mięśnia sercowego, } \\
\text { rotawirusy/Other: septi- } \\
\text { caemia, fungal infection, } \\
\text { conjunctivitis, meningi- } \\
\text { tis, CNS infection, UTI, } \\
\text { myocarditis, rotavirus }\end{array}$ & $15(27,27 \%$ \\
\hline
\end{tabular}

Źródło: opracowanie własne.

Source: author's own analysis

Najczęstszym rodzajem infekcji wśród noworodków hospitalizowanych w Klinice Neonatologii PUM w Policach było zapalenie płuc (56,36\%) (Tabela 2).

Tabela 2. Analiza infekcji występujących wśród hospitalizowanych dzieci Table 2. Analysis of infections in hospitalized children

\begin{tabular}{lcc}
\hline \multicolumn{1}{c}{ Rodzaj infekcj//Type of infections } & $\mathrm{N}$ & $\%$ \\
\hline Zapalenie płuc/Pneumonia & 31 & 56,36 \\
Zakażenie okołoporodowe/wewnątrzmaciczne/ & 9 & 16,36 \\
Perinatal/intrauterine infection & 15 & 27,27 \\
\hline Inne/Other &
\end{tabular}

Źródło: opracowanie własne.

Source: author's own analysis
W Klinice Neonatologii PUM najczęściej wśród dzieci występowały bakterie chorobotwórcze typu Escherichia coli (14,55\%) oraz Klebsiella pneumoniae (14,55\%) (Tabela 3).

Tabela 3. Analiza drobnoustrojów chorobotwórczych występujących wśród hospitalizowanych dzieci

Table 3. Analysis of pathogenic microorganisms found in hospitalized children

\begin{tabular}{lll}
\hline \multicolumn{1}{c}{ Drobnoustroje } & N & $\%$ \\
\hline Escherichia coli & 8 & 14,55 \\
\hline Klebsiella pneumoniae & 8 & 14,55 \\
\hline Enterobacter cloacae & 5 & 9,09 \\
\hline Citrobacter freundii & 4 & 7,27 \\
\hline Enterococcus faecalis & 4 & 7,27 \\
\hline Candida albicans & 3 & 5,45 \\
\hline Streptococcus agalactiae & 3 & 5,45 \\
\hline Enterobacter asburiae & 2 & 3,64 \\
\hline Klebsiella oxytoca & 2 & 3,64 \\
\hline Pseudomonas aeruginosa & 2 & 3,64 \\
\hline Staphylococcus epidermidis & 2 & 3,64 \\
\hline Acinetobacter dijkhoorniae & 1 & 1,82 \\
\hline Adenowirus & 1 & 1,82 \\
\hline Citrobacter braaki & 1 & 1,82 \\
\hline Escherichia hermanni & 1 & 1,82 \\
\hline Haemophilus infuenzae & 1 & 1,82 \\
\hline Rotawirus & 1 & 1,82 \\
\hline Streptococcus pneumoniae & 1 & 1,82 \\
\hline Streptococcus salivarius & 1 & 1,82 \\
\hline
\end{tabular}

Odsetki nie sumują się do 100, gdyż każde dziecko mogło mieć kilka drobnoustrojów/Percentages do not add up to 100 since each child may have had several microorganisms

Źródło: opracowanie własne.

Source: author's own analysis

Analizując wartości stężenia CRP i WBC we krwi noworodka jako badania najbardziej pomocnego w wykrywaniu infekcji, wykazano, iż występują podobnie wartości powyżej normy. Białko C-reaktywne wynosiło 43,64\%, a stężenie leukocytów 38,18\%. Wyniki nie różniły się znacząco, ale można stwierdzić, że bardziej pomocne w wykrywaniu infekcji u dzieci było CRP (Tabela 4).

Tabela 4. Analiza badania CRP i WBC jako przydatności w wykrywaniu infekcji u noworodka

Table 4. Analysis of C-reactive protein and white blood cells testing as useful in detecting infections in newborns

\begin{tabular}{|c|c|c|c|}
\hline \multicolumn{2}{|c|}{ Badania diagnostyczne/Diagnostic tests } & $\mathrm{N}$ & $\%$ \\
\hline \multirow{2}{*}{$\mathrm{CRP} / \mathrm{C}$-reactive protein } & W normie/Normal & 31 & 56,36 \\
\hline & Powyżej normy/Above norm & 24 & 43,64 \\
\hline \multirow{2}{*}{ Leukocytoza/Leukocytosis } & W normie/Normal & 34 & 61,82 \\
\hline & Powyżej normy/Above norm & 21 & 38,18 \\
\hline
\end{tabular}

Źródło: opracowanie własne.

Source: author's own analysis 
Kolejnym etapem badań była analiza czasu zakończenia ciąży oraz rodzaju porodu jako czynników determinujących wystąpienia różnego rodzaju infekcji u noworodków. W rezultacie wykazano istotną zależność pomiędzy czasem porodu a częstością występowania zakażeń $(p=0,001)$. $Z$ danych w Tabeli 5 . wynika, że u dzieci urodzonych przedwcześnie, wśród różnych rodzajów zakażeń, dominowały zapalenia płuc, czego nie obserwowano wśród noworodków urodzonych o czasie.

Nie stwierdzono istotnej zależności między rodzajem porodu a występowaniem zakażeń u dzieci $(p=0,083)$ (Tabela 5).

Tabela 5. Analiza zależności pomiędzy czasem zakończenia ciąży i rodzajem porodu a rodzajem występowania infekcji u dzieci Table 5. Analysis of the relationships between time and type of delivery and type of infection in children

\begin{tabular}{lcccc}
\hline & \multicolumn{2}{c}{$\begin{array}{c}\text { Czas porodu/ } \\
\text { Time of delivery }\end{array}$} & \multicolumn{2}{c}{$\begin{array}{c}\text { Rodzaj porodu/ } \\
\text { Type of delivery }\end{array}$} \\
\cline { 2 - 5 } \multicolumn{1}{c}{ Rozpoznanie } & $\begin{array}{c}\text { Wcześniak/ } \\
\text { Premature } \\
(\mathrm{N}=31)\end{array}$ & $\begin{array}{c}\text { Donoszony/ } \\
\text { Full }- \text { term } \\
(\mathrm{N}=24)\end{array}$ & $\begin{array}{c}\text { Drogami } \\
\text { natury/ }\end{array}$ & $\begin{array}{c}\text { Cięcie } \\
\text { Natural } \\
\text { cesarskie/ } \\
\text { Caesarean } \\
\text { section } \\
(\mathrm{N}=35)\end{array}$ \\
\hline $\begin{array}{l}\text { Zapalenie płuc/ } \\
\text { Pneumonia }\end{array}$ & (24) $77,42 \%$ & (7) $29,17 \%$ & (8) $40,0 \%$ & (23) $65,71 \%$ \\
$\begin{array}{l}\text { Zakażenie około- } \\
\text { porodowe/ } \\
\text { wewnątrzma- } \\
\text { ciczne/ }\end{array}$ & & & & \\
$\begin{array}{l}\text { Perinatal/intrau- } \\
\text { terine infection }\end{array}$ & (1) $3,23 \%$ & (8) $33,33 \%$ & (6) $30,0 \%$ & (3) $8,57 \%$ \\
$\begin{array}{l}\text { Inne zakażenia/ } \\
\text { Other infection }\end{array}$ & (6) $19,35 \%$ & (9) $37,5 \%$ & (6) $30,0 \%$ & (9) $25,71 \%$ \\
$p$ & \multicolumn{3}{c}{0,001} & \multicolumn{2}{c}{0,083} \\
\hline
\end{tabular}

$\mathrm{p}$ - test Fishera Freemana-Haltona

Źródło: opracowanie własne.

Source: author's own analysis

Analizie poddano również związek punktacji noworodka w skali Apgar z wystąpieniem infekcji u dzieci. Zauważono, iż wartość punktacji nie miała związku $z$ występowaniem infekcji ( $p=0,059)$. Zarówno noworodki w stanie średnim, jak i w dobrym najczęściej chorowały na zapalenie płuc (78,95\%; 44,44\%) (Tabela 6).

Kolejnym krokiem badań była analiza związku wagi urodzeniowej noworodków z wystąpieniem infekcji. Stwierdzono istotną zależność pomiędzy wagą urodzeniową dzieci a występowaniem zakażeń ( $p=0,01)$. Jak wynika z tabeli 7, u dzieci ważących poniżej 2500 g odsetek zapaleń płuc był wyższy aniżeli u noworodków z wagą $\leqslant 2500 \mathrm{~g}(72,41 \%$; vs. $38,46 \%)$ (Tabela 7$)$.
Tabela 6. Analiza zależności pomiędzy punktacją noworodka w skali Apgar a rodzajem występowania infekcji u dzieci

Table 6. Analysis of the relationships between Apgar scores and type of infection in children

\begin{tabular}{|c|c|c|c|}
\hline & \multicolumn{2}{|c|}{ Skala Apgar/Apgar score } & \multirow[t]{2}{*}{$p$} \\
\hline & $\begin{array}{l}\text { Stan średni } \\
\qquad(4-7) \\
(\mathrm{N}=19)\end{array}$ & $\begin{array}{c}\text { Stan dobry } \\
(8-10) \\
(\mathrm{N}=36)\end{array}$ & \\
\hline Zapalenie płuc/Pneumonia & (15) $78,95 \%$ & (16) $44,44 \%$ & \multirow{3}{*}{0,059} \\
\hline $\begin{array}{l}\text { Zakażenie okołoporodowe/ } \\
\text { wewnątrzmaciczne/ } \\
\text { Perinatal/intrauterine infection }\end{array}$ & (1) $5,26 \%$ & (8) $22,22 \%$ & \\
\hline Inne/Other & (3) $15,79 \%$ & (12) $33,33 \%$ & \\
\hline
\end{tabular}

$\mathrm{p}$ - test Fishera Freemana-Haltona

Źródło: opracowanie własne.

Source: author's own analysis

Tabela 7. Analiza zależności pomiędzy masą urodzeniową a rodzajem występowania infekcji u dzieci

Table 7. Analysis of the relationship between birth weight and type of infection in children

\begin{tabular}{lccc}
\hline \multirow{2}{*}{ Rozpoznanie } & \multicolumn{2}{c}{$\begin{array}{c}\text { Waga urodzeniowa/Birth } \\
\text { weight }\end{array}$} & \multirow{2}{*}{$\mathrm{p}$} \\
\cline { 2 - 3 } & $\begin{array}{c}\leqslant 2500 \mathrm{~g} \\
(\mathrm{~N}=26)\end{array}$ & $\begin{array}{c}>2500 \mathrm{~g} \\
(\mathrm{~N}=29)\end{array}$ & \\
\hline $\begin{array}{l}\text { Zapalenie płuc/Pneumonia } \\
\text { Zakażenie okołoporodowe/ }\end{array}$ & $\begin{array}{l}\text { (10) } 38,46 \% \\
\text { wewnątrzmaciczne/ }\end{array}$ & (21) $72,41 \%$ & \multirow{2}{*}{0,01} \\
$\begin{array}{l}\text { Perinatal/intrauterine infection } \\
\text { Inne/Other }\end{array}$ & (8) $30,77 \%$ & (1) $3,45 \%$ & \\
\hline
\end{tabular}

$\mathrm{p}$ - test Fishera Freemana-Haltona

Źródło: opracowanie własne.

Source: author's own analysis

Przeprowadzając analizę materiału, konieczne wydawało się sprawdzenie zależności pomiędzy przedwczesnym odpływaniem płynu owodniowego (PROM) i czasem jego odpływania a rodzajem występowania infekcji u dzieci. Wykazano, iż PROM nie miał istotnego związku $z$ występowanie infekcji $u$ dzieci $(p=1)$. Zarówno noworodki urodzone z ciąż z PROM lub bez w ponad 56,0\% częściej chorowały na zapalenie płuc (Tabela 8).

Analizując czas odpływania płynu owodniowego wykazano, iż w przypadku gdy wody płodowe odpływały do 6 godzin przed porodem, u noworodków dominowały zakażenia „inne” (40,0\%). Natomiast jeżeli płyn owodniowy odpływał powyżej 6 godzin, dominowało zapalenie płuc u noworodków (75,0\%). Nie wykazano istotności statystycznej $(p>0,05)$ (Tabela 8). 
Tabela 8. Analiza zależności pomiędzy PROM i czasem odpływania wód płodowych a rodzajem występowania infekcji u dzieci

Table 8. Analysis of the relationships between premature rupture of membranes, time of water breaking, and type of infection in children

\begin{tabular}{|c|c|c|c|c|}
\hline \multirow{2}{*}{ Rozpoznanie } & \multicolumn{2}{|c|}{$\begin{array}{c}\text { PROM/ } \\
\text { Premature rupture } \\
\text { of membranes }\end{array}$} & \multicolumn{2}{|c|}{$\begin{array}{c}\text { Czas odpływania } \\
\text { płynu owodniowego/ } \\
\text { Time of water breaking }\end{array}$} \\
\hline & $\begin{array}{l}\text { Tak/Yes } \\
(\mathrm{N}=23)\end{array}$ & $\begin{array}{l}\mathrm{Nie} / \mathrm{No} \\
(\mathrm{N}=32)\end{array}$ & $\begin{array}{l}<6 h \\
(N=10)\end{array}$ & $\begin{array}{l}>6 h \\
(N=12)\end{array}$ \\
\hline $\begin{array}{l}\text { Zapalenie płuc/ } \\
\text { Pneumonia }\end{array}$ & (13) $56,52 \%$ & (18) $56,25 \%$ & (3) $30,0 \%$ & (9) $75,0 \%$ \\
\hline $\begin{array}{l}\text { Zakażenie } \\
\text { okołoporodowe/ } \\
\text { wewnątrzmaciczne/ } \\
\text { Perinatal/intrauterine } \\
\text { infection }\end{array}$ & (4) $17,39 \%$ & (5) $15,62 \%$ & (3) $30,0 \%$ & (1) $8,33 \%$ \\
\hline Inne/Other & (6) $26,09 \%$ & (9) $28,12 \%$ & (4) $40,0 \%$ & (2) $16,67 \%$ \\
\hline$p$ & 1 & 1 & & 135 \\
\hline
\end{tabular}

$\mathrm{p}$ - test Fishera Freemana-Haltona

Źródło: opracowanie własne.

Source: author's own analysis

Ważnym aspektem przeprowadzonych badań było stwierdzenie, czy występowanie infekcji oraz chorób wspótistniejących u matki w czasie ciąży było czynnikiem determinującym występowanie infekcji u dziecka po porodzie. Nie wykazano różnic istotnych statystycznie $(p>0,05)$. Zarówno u dzieci matek, u których infekcje wystąpiły w ciąży, jak i nie wystąpiły, stwierdzono podobny odsetek zapalenia płuc, jednakże odsetek ten był większy u dzieci kobiet z infekcjami w czasie ciąży $(63,64 \%)$.

Biorąc pod uwagę wystąpienie chorób współistniejących w ciąży również dominował odsetek zapaleń płuc u dzieci, jednakże odsetek ten był większy u noworodków kobiet bez chorób w czasie ciąży (65,0\%) (Tabela 9).

Tabela 9. Analiza zależności pomiędzy występowaniem infekcji i chorób współistniejących u matki podczas trwania ciąży a rodzajem infekcji u dzieci

Table 9. Analysis of the relationships between the occurrence of infections and comorbidities in mother during pregnancy and type of infection in children

\begin{tabular}{|c|c|c|c|c|}
\hline \multirow{2}{*}{$\begin{array}{l}\text { Rozpoznanie/ } \\
\text { Diagnosis }\end{array}$} & \multicolumn{2}{|c|}{$\begin{array}{l}\text { Infekcje u matki/ } \\
\text { Infections in mother }\end{array}$} & \multicolumn{2}{|c|}{$\begin{array}{l}\text { Choroby wspótistnieją- } \\
\text { ce u matki/ } \\
\text { Comorbidities in mother }\end{array}$} \\
\hline & $\begin{array}{l}\text { Tak/Yes } \\
(\mathrm{N}=11)\end{array}$ & $\begin{array}{l}\mathrm{Nie} / \mathrm{No} \\
(\mathrm{N}=44)\end{array}$ & $\begin{array}{l}\text { Tak/Yes } \\
(\mathrm{N}=35)\end{array}$ & $\begin{array}{l}\mathrm{Nie} / \mathrm{No} \\
(\mathrm{N}=20)\end{array}$ \\
\hline $\begin{array}{l}\text { Zapalenie płuc/ } \\
\text { Pneumonia }\end{array}$ & (7) $63,64 \%$ & (24) $54,55 \%$ & (18) $51,43 \%$ & (13) $65,0 \%$ \\
\hline $\begin{array}{l}\text { Zakażenie okołopo- } \\
\text { rodowe/ } \\
\text { wewnątrzmaciczn/ } \\
\text { Perinatal/intrauterine } \\
\text { infection }\end{array}$ & (1) $9,09 \%$ & (8) 18,18\% & (6) $17,14 \%$ & (3) $15,0 \%$ \\
\hline Inne/Other & (3) $27,27 \%$ & (12) $27,27 \%$ & (11) $31,43 \%$ & (4) $20,0 \%$ \\
\hline$p$ & & 899 & 0,5 & \\
\hline
\end{tabular}

$\mathrm{p}$ - test Fishera Freemana-Haltona

Źródło: opracowanie własne.

Source: author's own analysis
Podczas badań analizie poddano również zależność występowania dodatniego nosicielstwa paciorkowca B-hemolizującego u kobiety w czasie ciąży na wystąpienie infekcji u noworodka. Wykazano, iż u matek dzieci $z$ dodatnim wynikiem GBS nie stwierdzono jednoznacznego ryzyka transmisji, gdyż $25,0 \%$ dzieci było nim zainfekowanych, $25,0 \%$ nie było, natomiast nie pozyskano danych od 50,0\% ciężarnych (Tabela 10).

Tabela 10. Wpływ dodatniego nosicielstwa GBS u matki a ryzyko transmisji wertykalnej na noworodka w okresie okołoporodowym Table 10. Effect of Group B streptococcus positivity in mother and risk of vertical transmission to newborn in the perinatal period

\begin{tabular}{lcc}
\multicolumn{1}{c}{$\begin{array}{c}\text { GBS u dzieci matek z GBS/ } \\
\text { GBS in newborns of mothers with GBS }\end{array}$} & N & $\%$ \\
\hline Tak/Yes & 2 & $25,0 \%$ \\
Nie/No & 2 & $25,0 \%$ \\
Brak danych/No data & 4 & $50,0 \%$ \\
\hline
\end{tabular}

Źródło: opracowanie własne

Source: author's own analysis

\section{Dyskusja}

Rozwój układu odpornościowego niesie ze sobą szereg zmian, które mają miejsce w pierwszych latach życia dziecka. Noworodki, a zwłaszcza wcześniaki, są do pewnego stopnia osłabione immunologicznie $z$ uwagi na niedojrzałość układu odpornościowego oraz zmniejszonego przenikania przez łożysko przeciwciał matczynych. Niedojrzały układ odpornościowy noworodków przyczynia się do zwiększonej podatności na poważne infekcje bakteryjne, wirusowe i grzybicze [1].

W badaniach własnych wykazano, że najczęstszym rodzajem infekcji wśród dzieci hospitalizowanych w Klinice Neonatologii PUM w Policach było zapalenie płuc (56,36\%). Zakażenie okołoporodowe/wewnątrzmaciczne pojawiło się u 16,36\% dzieci, natomiast "inne" rodzaje infekcji występowały u 27,27\% badanych. Zaobserwowano także istotność statystyczną wykazującą, że czas porodu istotnie wpływał na rodzaj występowania infekcji u noworodka. U wcześniaków dominowało zapalenie płuc, natomiast u dzieci urodzonych o czasie zakażenia „inne”. W wielu publikacjach podkreśla się, że zapalenie płuc stanowi znaczną część zachorowalności u noworodków [2]. W badaniach Khamina i wsp. [3] zapalenie płuc stanowiło główny odsetek zachorowalności $(29,6 \%)$. Takie spostrzeżenia poczynił także Elster i wsp. [4], którzy wykazali, że dominującą postacią infekcji również było zapalenie płuc $(56,96 \%)$ i to w prawie identycznym odsetku w odniesieniu do badań własnych. Oprócz zakażeń układu oddechowego w badaniach własnych wykryto pod postacią „inne”: posocznicę, zapalenie opon mózgowo-rdzeniowych, zapalenie centralnego układu nerwowego, biegunkę rotawirusową, zapalenie układu moczowego, zapalenie mięśnia 
sercowego oraz zapalenie spojówek. Także Elster i wsp. [4] potwierdzili w badaniach zakażenie uogólnione oraz zakażenie układu moczowego u dzieci.

Badania własne wykazały, że najczęściej z pobieranych wymazów oraz posiewów wśród dzieci występowały drobnoustroje chorobotwórcze typu: Escherichia coli $(14,55 \%)$ i Klebsiella pneumoniae (14,55\%) oraz Enterobacter cloacae (9,09\%). Podobne wyniki uzyskał Markic i wsp. [5], gdzie Escherichia coli, Klebsiella pneumoniae i Enterococcus były odpowiedzialne w tym badaniu przede wszystkim za ZUM, a w drugiej kolejności za zapalenie płuc. Natomiast w pracy Shatalova i wsp. [6] wśród bakterii Gram-ujemnych najczęstszym typem była Klebsiella pneumoniae $(69,6 \%)$, a następnie Escherichia coli $(13,8 \%)$ w rozpoznaniu wczesnej sepsy. Identyczne dane można zaobserwować u Lim`a i wsp. [7], gdzie na pierwszym miejscu była Klebsiella pneumoniae (33,9\%), a na drugim Escherichia coli (28,6\%). Chociaż w ostatnim dziesięcioleciu kilka badań ujawniło przede wszystkim wzrost odsetka posocznicy o charakterze Escherichia coli szczególnie u wcześniaków [8]. Aczkolwiek w innych dostępnych publikacjach to Streptococcus agalactiae jest wiodącym patogenem. W wielu placówkach będących pod nadzorem Nationalatnation Health and Development's Neonatal Research Network i dużej sieci Pediatrix częstość występowania GBS była wyższa niż w przypadku E. coli. Ogólnokrajowy nadzór w Holandii i Włoszech również wykazuje, że paciorkowiec grupy B występuje częściej [9]. Jednak w badaniach własnych Streptococcus agalactiae występował w małym odsetku (5,45\%). Według Stoll i wsp. [8] E. coli pozostaje najczęstszym patogenem u wcześniaków, a GBS przede wszystkim u niemowląt urodzonych o czasie w postaci zapalenia płuc i posocznicy.

W badaniach własnych kobiety podzielono na trzy grupy: ciężarne, u których wykryto nosicielstwo paciorkowcem grupy B; ciężarne, u których nie wykryto GBS oraz kobiety, które nie miały wyniku. Następnie zbadano, czy dodatni wynik GBS u rodzących miał wpływ na rodzaj infekcji u dzieci. Nie stwierdzono jednak jednoznacznego ryzyka transmisji, gdyż tyle samo dzieci było nim zakażonych, co nie było, przy braku danych połowy kobiet. Brak wyniku u kobiet ciężarnych może wynikać z porodów przedwczesnych, kiedy pacjentka nie zdążyła wykonać jeszcze badania przesiewowego. Według standardów opieki okołoporodowej posiew wykonuje się między 35. a 37. tygodniem ciąży. W tym przypadku status mikrobiologiczny jest niewiadomy i należy pacjentce w takiej sytuacji włączyć profilaktykę okołoporodową, aby zapobiec zakażeniom GBS [10].

W badaniach własnych zauważono, że masa urodzeniowa noworodka miała istotny związek z występowaniem infekcji. U noworodków o masie poniżej 2500 g odsetek zapaleń płuc był wyższy aniżeli u dzieci z wyższą wagą urodzeniową. Potwierdzą to badania Wójkowskiej-Mach i wsp. [11], które wykazały, że najwyższa zapadalność potwierdza się w grupie noworodków o masie urodzeniowej 1500 g, gdzie zapalenie płuc było najwyższym wskaźnikiem zachorowalności. Również Elster i wsp. [4] wykazali, że istotnym czynnikiem ryzyka infekcji była niska masa urodzeniowa - poniżej 2000 g. Podobne wnioski wysunęli Vergnano i wsp. [12], którzy opisali ciężar infekcji w wielu angielskich oddziałach noworodkowych i doszli do wniosku, że wcześniaki i dzieci z niską masą urodzeniową są najbardziej obciążone infekcją, a 26,0\% wszystkich dzieci < $1000 \mathrm{~g}$ doświadcza jednego lub więcej epizodów infekcji podczas pobytu w szpitalu. Zakażenia noworodków w tej populacji są związane z przedłużającą się hospitalizacją, niekorzystnym wynikiem neurorozwojowym i zwiększoną śmiertelnością. Większość epizodów zakażenia (82,0\%) wystąpiła u noworodków urodzonych < 37. tygodniu ciąży. Podobnie, bo aż 81,0\% epizodów wystąpiło u noworodków o masie urodzeniowej $<2500 \mathrm{~g}$, a 53,0\% wystąpiło u dzieci < $1000 \mathrm{~g}$.

W badaniach własnych nie zaobserwowano zależności pomiędzy typem porodu a występowaniem infekcji u dzieci, ponieważ zarówno u dzieci urodzonych poprzez cięcie cesarskie, jak i u dzieci z porodu fizjologicznego odsetek zapaleń płuc był wyższy od innych infekcji (65,71\% vs. $40,00 \%)$. Natomiast według Vissinga i wsp. [13] częstość występowania zapalenia płuc była istotnie związana z porodem przez cesarskie cięcie oraz wiązało się z 1,5-krotnie większą częstością występowania zapalenia płuc i zapalenia oskrzelików. Podobne wnioski wysunął Mylonas i wsp. [14] podając, że noworodki urodzone przez cesarskie cięcie cesarskie mają większe ryzyko powikłań oddechowych. Także Gouyon i wsp. [15] przedstawili poród przez cięcie cesarskie jako główny czynnik chorobotwórczy układu oddechowego, zarówno u noworodków urodzonych przedwcześnie, jak i u donoszonych, w porównaniu z dziećmi urodzonymi siłami natury.

Porównano także stan noworodka po porodzie a występowanie zakażeń. Przeprowadzona analiza materiału nie wykazała istotności statystycznej w wartości punktacji noworodka w skali Apgar na charakter występowania infekcji u dzieci. Zarówno dzieci w stanie średnim, jak i w dobrym najczęściej chorowały na zapalenie płuc $(78,95 \%$ vs. 44,44\%). Costa i wsp. [16] w swoich badaniach wykazali, że niższą ocenę w skali Apgar w ciągu 1. i 5. minuty zaobserwowano u noworodków z zapaleniem płuc w porównaniu z grupą kontrolną. Niższa punktacja może być związana z czasem i sposobem nabycia infekcji. Stwierdzenie niskiej punktacji w skali Apgar w ciągu 1. i 5. minuty w tej grupie pa- 
cjentów sugeruje, że reakcja zapalna obecna była już w chwili urodzenia, w związku z tym większość z tych przypadków była prawdopodobnie wrodzonym lub wewnątrzmacicznym zapaleniem płuc.

W badaniach własnych wykazano, że przedwczesne odpływanie płynu owodniowego nie miało bezpośredniego związku z występowaniem infekcji u dzieci. Zarówno u noworodków urodzonych z ciąż z PROM, jak i bez, odsetek zapaleń płuc był wyższy od innych zakażeń. Również czas odpływania płynu owodniowego nie miał istotnego związku z występowaniem zakażeń u dzieci. Jednakże w przypadku, gdy płyn owodniowy odpływał do 6 godzin przed porodem dominowały infekcje „inne”. Natomiast jeżeli wody płodowe odpływały powyżej 6 godzin dominowało zapalenie płuc. Przedwczesne pęknięcie błon płodowych i infekcje noworodków są ściśle powiązane. Dawniej sądzono, że im PROM będzie dłużej trwał, to częstość zakażeń u noworodka wzrośnie, a stopień infekcji będzie zasadniczo poważniejszy. Badania Liu i wsp. [2] wykazały, że czas trwania PROM i częstość infekcji nie mają związku. W przypadku noworodków donoszonych przedwczesne odpływanie wód płodowych u matki trwające $\leqslant 24$ godziny dało wynik dodatni posiewu krwi u 7,7\% pacjentów, przy czasie wynoszącym 24-72 godziny wskaźnik wyniósł $7,2 \%$, a przy PROM > 72 h wskaźnik ten stanowił 9,6\%. Różnice przy dodatnim posiewie krwi w rozbieżności czasowej trwania PROM nie były istotne statystycznie. Jednak Wu i wsp. [17], przeprowadzając badania w Chinach zgodnie z obecnością lub brakiem PROM u ciężarnych, porównali grupę kontrolną z czasem trwania PROM < 72 h i wykazali, że czas trwania $\mathrm{PROM} \geqslant 72$ godziny wykazał jednak istotnie częstsze występowanie zapalenia płuc.

W badaniach własnych nie wykazano istotnych statystycznie różnic w przypadku występowania infekcji i chorób współistniejących u matki podczas trwania ciąży a rodzajem występowania infekcji u dzieci. Zarówno u dzieci matek, u których infekcje i choroby wystąpiły w ciąży, jak i nie wystąpiły, stwierdzono podobny odsetek zapalenia płuc. Jednak liczba matek, u których stwierdzono choroby współistniejące, była większa w porównaniu z matkami negującymi choroby współistniejące. W analizowanym materiale nie wykryto bezpośredniego wpływu chorób i infekcji u rodzących na wystąpienie zakażeń u noworodków, ale można wywnioskować, że ciążowe zakażenie układu moczowo-płciowego może przyczyniać się do ryzyka wystąpienia porodu przedwczesnego, wcześniactwa, urodzenia dziecka z niską masą ciała $(<2500 \mathrm{~g})$ i śmiertelnością okołoporodową [18, 19].

Badania nad markerami zakażeń są szczególnie ważne w neonatologii, ze względu na większą liczbę ciężkich uogólnionych zakażeń, które dotyczą noworodków. Oznaczanie CRP jest badaniem powszechnym w diagnostyce infekcji. Pozwala monitorować przebieg leczenia, umożliwia określenie czasu podawania antybiotykoterapii oraz wystąpienie powikłań [20]. W badaniach własnych zaobserwowano występowanie podobnych wartości stężenia powyżej normy CRP (43,64\%) oraz stężenia leukocytów (38,18\%) w surowicy krwi noworodka. Wyniki nie różniły się znacząco, ale można stwierdzić, że bardziej pomocne w wykrywaniu infekcji było białko C-reaktywne. W badaniach Zarkesha i wsp. [21] wartości predykcyjne CRP były wyższe niż liczba leukocytów (WBC, ang. white blood cells). Stwierdzono, że białko C-reaktywne jest lepszym markerem diagnostycznym do przewidywania zakażenia bakteryjnego (SBI, ang. severe bacterial infection) niż WBC oraz jest szeroko stosowanym markerem do wykrywania posocznicy. W innych doniesieniach także dokładniejszym predyktorem okazało się białko ostrej fazy niż oznaczenie liczby leukocytów. Markic i wsp. [22] podali, że graniczne wartości CRP miały lepszą czułość i swoistość niż wartości graniczne WBC. Wyniki pokazują, że białko ostrej fazy ma niestety ograniczoną możliwość wykluczenia wszystkich infekcji bakteryjnych ze względu na nakładanie się wartości CRP u noworodków z infekcjami bakteryjnymi i wirusowymi. Na podstawie tych wyników potwierdzono, że CRP i WBC są przydatnymi markerami do różnicowania poważnego zakażenia bakteryjnego.

\section{Wnioski}

1. Wcześniactwo oraz niska masa urodzeniowa są istotnymi czynnikami determinującymi występowanie zapalenia płuc u noworodków.

2. Przedwczesne odpływanie płynu owodniowego odrębnie nie ma szczególnego związku z występowaniem infekcji u noworodków, ale jeśli wody płodowe odpływają powyżej 6 godzin dominuje zapalenie płuc.

3. Dodatni wynik nosicielstwa GBS u matki nie jest jednoznacznym ryzykiem transmisji wertykalnej na noworodka w okresie okołoporodowym.

\section{Piśmiennictwo}

1. Cortese F, Scicchitano P, Gesualdo M, Filaninno A, Giorgi ED, Schettini $F$ et al. Early and late infections in newborns: where do we stand? A review. Paediatr Neonatol. 2016; 57(4): 265273. http//doi.org/10.1016/j.pedneo.2015.09.007.

2. Liu J. Infectious pneumonia of the newborn. In: Liu J, Sorantin E, Cao HY eds. Neonatal lung ultrasonography. Dordrecht: Springer Nature B.V. and People's Medical Publishing House; 2018, s. 78-88. https://doi.org/10.1007/97894-024-1549-0.

3. Khamin A, Islam S, Bora R, Paul N, Ramasamy S. Pattern of respiratory problems in neonates in a level III neona- 
tal care unit with special reference to pneumonia. Indian $\mathrm{J}$ Neonatal Med Res. 2016; 4(4): PO01-PO05. doi: 10.7860/ IJNMR/2016/22669.2189.

4. Elster T, Czeszyńska BM, Sochaczewska D, Konefał H, Baryła-Pankiewicz E. Analiza czynników ryzyka zakażeń szpitalnych w Oddziale Intensywnej Terapii Noworodka Kliniki Neonatologii PAM w Szczecinie w latach 2005-2008. Ginekol Pol. 2009; 80(8): 609-614.

5. Markic J, Jeroncic A, Polancec D, Bosnjak N, Markotic A, Mestrovic $\mathrm{J}$ et al. CD15s is potential biomarker of serious bacterial infection in infants admitted to hospital. Eur $\mathrm{J} \mathrm{Pe}$ diatr. 2013; 172(10): 1363-1369.

6. Shatalov A, Awwad F, Mangue P, Foqahaa R. Predominance of multi-drug resistant klebsiella pneumonia and other gram negative bacteria in neonatal sepsis in Equatorial Guinea. Open J Med Microbiol. 2015; 5(4): 254-258. http:// dx.doi.org/10.4236/ojmm.2015.54031.

7. Lim WH, Lien R, Huang YC, Chiang SM, Fu RH, Chu SM et al. Prevalence and pathogen distribution of neonatal sepsis among very-low-birth-weight infants. Pediatr Neonatol. 2012; 53(4): 228-234. https://doi.org/10.1016/j.pedne0.2012 .06 .003

8. Stoll BJ, Hansen NI, Sánchez PJ, Faix RG, Poindexter BB, Van Meurs KP et al.: Early onset neonatal sepsis: the burden of group B Streptococcal and E. coli disease continues. Pediatrics. 2011; 127(5): 817-826. https://doi: 10.1542/ peds.2010-2217.

9. Schrag SJ, Farley SS, Petit S, Reingold A, Weston EJ, Pondo $T$ et al. Epidemiology of invasive early-onset neonatal sepsis, 2005 to 2014. Pediatrics. 2016; 138(6): e20162013. https//doi.org/10.1542/peds.2016-2013.

10. Szwabowicz K, Panasiuk A. Nosicielstwo paciorkowca grupy B u kobiet ciężarnych - standardy postępowania. Prz Epidemiol. 2012;66(1): 33-38.

11. Wójkowska-Mach J, Borszewska-Kornacka M, Domańska J, Gadzinowski J, Gulczyńska E, Helwich E et al. Early-onset infections of very-low-birth-weight Infants in Polish neonatal intensive care units. Pediatr Infect Dis J. 2012;31(7):691695. http//doi: 10.1097/ INF. 0b013e3182567b74.

12. Vergnano S, Menson E, Kennea N, Embleton N, Russell $A B$, Watts $T$ et al.: Neonatal infections in England: the NeonIN surveillance network. Arch Dis Child Fetal Neonatal Ed. 2011;96(1):F9-F14. http://dx.doi.org/10.1136/ adc.2009.178798.

13. Vissing NH, Chawes BLK, Bisgaard $\mathrm{H}$. Increased risk of pneumonia and bronchiolitis after bacterial colonization of the airways as neonates Am J Respir Crit Care Med. 2013; 188(10): 1246-1252. doi: 10.1164/rccm.201302-0215OC.

14. Mylonas I, Friese K. Indications for and risks of elective cesarean section. Dtsch Arztebl Int. 2015; 112(29-30): 48995. doi:10.3238/arztebl.2015.0489.
15. Gouyon JB, lacobelli S, Ferdynus, Bonsante F. Neonatal problems of late and moderate preterm infants. Semin Fetal Neonatal Med. 2012; 17(3): 146-152.

16. Costa S, Rocha G, Leitão A, Guimarães H. Transient tachypnea of the newborn and congenital pneumonia: a comparative study. J Matern Fetal Neonatal Med. 2012; 25(7) 992-994. https://doi.org/10.3109/14767058.2011.604366.

17. Wu T, Shi J, Bao S, Qu Y, Mu DZ. Effect of premature rupture of membranes on maternal infections and outcome of preterm infants. Chin J Contemp Pediatr. 2017; 19(8): 861865. Doi: 10.7499/j.issn.1008-8830.2017.08.004.

18. Szałek E, Tomczak H, Kamińska A, Korzeniowska K, Grześkowiak E. Bakteryjne zakażenia układu moczowego u kobiet w ciąży. Farm Współcz. 2011; 4(4): 166-170.

19. Fichorova RN, Beatty N, Sassi RRS, Yamamoto HS, Allred EN, Leviton A. Systemic inflammation in the extremely low gestational age newborn following maternal genitourinary infections. Am J Reprod Immunol. 2014; 73(2): 162-174. https://doi.org/10.1111/aji.12313.

20. Kwiatkowska-Gruca M, Behrendt J, Sonsala A, Wiśniewska -Ulfik D, Mazur B, Godula-Stuglik U. Presepsyna (rozpuszczalny podtyp CD14-ST) jako diagnostyczny biomarker posocznicy u noworodków. Pediatr Pol. 2013; 88(5): 392-397. https://doi.org/10.1016/j.pepo.2013.06.011.

21. Zarkesh, Sedaghat F, Heidarzadeh A, Tabrizi M, BolookiMoghadam K, Ghesmati S. Diagnostic value of IL-6, CRP, WBC and absolute neutrophil count to predict serious bacterial infection in febrile infants. Acta Med Iran. 2015; 53(7): 408-411. https://acta.tums.ac.ir/index.php/acta/article/view/4272.

22. Markic J, Kovacevic T, Krzelj V, Bosnjak N, Sapunar A. Labscore is a valuable predictor of serious bacterial infection in infants admitted to hospital. Wien Klin Wochenschr. 2015; 127(23-24): 942-947. doi: 10.1007/s00508-015-0831-6.

Artykuł przyjęty do redakcji: 13.10.2020.

Artykuł przyjęty do publikacji: 16.09.2021.

Źródło finansowania: Praca nie jest finansowana z żadnego źródła. Konflikt interesów: Autorzy deklarują brak konfliktu interesów.

Adres do korespondencji:
Katarzyna Szymoniak
ul. Żołnierska 48
71-210 Szczecin
e-mail: katarzyna.szymoniak@pum.edu.pl
Zakład Położnictwa i Patologii Ciąży, Wydział Nauk o Zdrowiu,
Pomorski Uniwersytet Medyczny

